\title{
Nursing Technology in Vibration Perception Threshold Testing in Diabetic Peripheral Neuropathy Patients
}

\author{
$1^{\text {st }}$ Kharisma Pratama \\ Department of Basic Nursing of \\ Science, Sekolah Tinggi Ilmu \\ Keperawatan Muhammadiyah \\ Pontianak \\ Kalimantan Barat, Indonesia \\ kharisma@stikmuhptk.ac.id \\ $4^{\text {th }}$ Didik Setiawan \\ Department of Pharmacology and \\ Clinical Pharmacy, Faculty of \\ Pharmacy \\ Universitas Muhammadiyah \\ Purwokerto \\ Jawa Tengah, Indonesia \\ $7^{\text {th }}$ Usman \\ Department of Basic Nursing of \\ Science, Sekolah Tinggi Ilmu \\ Keperawatan Muhammadiyah \\ Pontianak \\ Kalimantan Barat, Indonesia
}

\author{
$2^{\text {nd }}$ Suriadi \\ Department of Medical and Surgical \\ Nursing, Sekolah Tinggi Ilmu \\ Keperawatan Muhammadiyah \\ Pontianak \\ Kalimantan Barat, Indonesia
}

$5^{\text {th }}$ Asmiyenti Djaliasrin Djalil

Department of Pharmacology and

Clinical Pharmacy, Faculty of Pharmacy

Universitas Muhammadiyah Purwokerto

Jawa Tengah, Indonesia

$8^{\text {th }}$ Tisa Gusmiah

Department of Medical and Surgical

Nursing, Sekolah Tinggi Ilmu

Keperawatan Muhammadiyah Pontianak

Kalimantan Barat, Indonesia

\author{
$3^{\text {rd }}$ Gusti Jhoni Putra \\ Department of Medical and Surgical \\ Nursing, Sekolah Tinggi Ilmu \\ Keperawatan Muhammadiyah \\ Pontianak \\ Kalimantan Barat, Indonesia
}

\author{
$6^{\text {th }}$ Cau Kim Jiu \\ Department of Community Health \\ Nursing, Sekolah Tinggi Ilmu \\ Keperawatan Muhammadiyah \\ Pontianak \\ Kalimantan Barat, Indonesia
}

\begin{abstract}
Diabetic Peripheral Neuropathy (DPN) is one factor which can lead the diabetes mellitus patient to foot ulceration. Early detection is indispensable part to prevent diabetes mellitus patient from foot disorders. vibration perception threshold (VPT) measures can be used to easily and accurately identify presence of DPN. This study was to test the reliability and to evaluate the accuracy of a new vibrometer for detection DPN. A new device (Neovibrometer) was compared with $10 \mathrm{~g}$ monofilament and tested on a group of DPN and a group of healthy as matched control subjects. Vibration Perception Threshold (VPT) was tested on the plantar surface of the feet. The Neo-vibrometer shows an actual measurement in all test. The Pearson correlation coefficient was $0.94 \quad(P<0.05)$. The $10 \mathrm{~g}$ monofilament could also be measured with excellent reliability but only within a limited range of mild to moderate neuropathy, so it appears to be an appropriate screening tool. The measurement-to-measurement intraclass correlation coefficient was 0.93 . The new device is accurate and could measure of VPT. It could document loss of sensation in diabetic neuropathy even in the presence of a normal result when it tested by $10 \mathrm{~g}$ monofilament test. The Neo-vibrometer can be earlier detected of diabetic neuropathy and should be used as the recommended technique in diabetic foot ulcer prevention.
\end{abstract}

Keywords-Nursing Technology, Threshold Testing, Diabetic Peripheral Neuropathy

\section{INTRODUCTION}

Diabetic Peripheral Neuropathy (DPN) is one of DM complication which contributes in exacerbating ulceration. The DM patient with neuropathy complication has lost sensation as the main problem which increased incidences of diabetic foot ulcer (DFU) [1]. Approximately 15\% DM patients were suffer DFU and leading to death caused by sepsis [1].

Early detection is the gold manner to prevent DM patients from ulceration. The guidelines for detecting risk of DFU have been conducted from various organizations which concern to DFU prevention, include NICE, ADA, IDF, and also from many previous researchers. The guidelines for DFU prevention consist of risk assessment, risk category, and diabetic foot care.

The determination of the vibration perception threshold is one of steps in DFU risk assessment which used to assess of neuropathy. The patients will be categorized as high risk when signs of DPN detected. The increased VPT more than 25 Volt and lack of sensation indicate that DM patient has been undergone of peripheral nerve disorders [2].

Previous studies showed that monofilament and vibrometer are appropriate devices for detecting lack of sensation on DM patients. Both of devices are noninvasive and practically. Monofilament is single fiber nylon threads, used to detect the pressure of sensation in 
neuropathic patients. Reliability of monofilament has been done by the previous studies [3].

Currently, there are available devices for evaluating VPT, include the Neurothesiometer, and the Biothesiometer. Although these devices have similarities in measuring VPT, but it relatively expensive. In this study, the researcher has developed the new vibrometer (neovibrometer) which is inexpensive and more portable, easy to use, and practically. Furthermore, the Neo-vibrometer can be used by care givers or families patient's for optimally in prevention DM patient from DFU in community setting.

The aim of this study was to test the reliability and to evaluate the accuracy of a new vibrometer for detection DPN. This tool is only to determine the presence of neuropathy and not to distinguish the severity of neuropathy.

\section{METHODS AND PARTICIPANTS}

Forty participants (20 DPN and 20 non-diabetic) have been recruited from primary health services in IndonesiaMalaysia border. The study was approved by STIK Muhammadiyah Pontianak Review Board. All participants signed an inform consent form. Participants who were using medication that have an effect to central nervous system and have other neurological and musculoskeletal problems from other diseases were excluded.

\section{INSTRUMENTS AND STUDY PROCEDURES}

All of the participants were tested in the quite room. The monofilament test was done with a $10 \mathrm{~g}$ SemmesWeinstein filament. The monofilament was single perpendicular string that applied on the plantar surface at heel and hallux. During the monofilament test, the participants were suggested to remove shoes and socks and lay prone with eyes closed. The examiner tested the monofilament on the participant's hand before it tested on the plantar. the monofilament was touched to skin on plantar with straight until the string bended, approximately 10-12 seconds and asked the participant to give response "yes" when feel the sensation and "no" when did not feel sensation. The test sensation was repeated three times on plantar at heel and hallux. After an hour interval, the second examination was performed by using The Neo-vibrometer. The Neo-vibrometer consisted of a generator vibration with probe. During the Neo-vibrometer tested, participants was suggested to lay prone on the bed and removed shoes and socks. The examiners tried to apply the probe with vibration on the participant's hand to give the example vibration before applied on plantar surface at the heel and hallux. When the probe was applied on the plantar, the participants was instructed to say "yes" when felt the vibration and "no" when the vibration was absence. The voltage was increased gradually from 1 to 30 volts. The participants were categorized when test was done, consist of mild, moderate, and severe neuropathy. Participants called mild neuropathy when cannot feel the vibration on $16-20$ volts, moderate was on 21-25 volts, and severe neuropathy was above 25 volts.

\section{STATISTICAL ANALYSIS}

Statistical analyses were calculated by using SPSS. The demographic data were described by using descriptive statistic. Intra-class Correlation Coefficients (ICC) and Standard Error of the Mean (SEM) were calculated to evaluate within and between subject inter and intra rater reliability of $10 \mathrm{~g}$ Monofilament and NeoVibrometer. Based on Rosner's classification, ICC $\geq 0.75$ represent excellent, $0.4 \leq \mathrm{ICC}<0.75$ indicate fair to good, and $<0.4$ demonstrate poor reliability [3].

\section{RESULTS}

The means and SD of the right hallux and heel Neovibrometer and $10 \mathrm{~g}$ monofilament measurements in every group are presented in table 1 .

TABLE 1. AVERAGE CATEGORY LOSS OF SENSATION FOR THE RIGHT HALLUX AND HEEL FOR 20 CONTROL AND 20 NEUROPATHIC PARTICIPANTS TESTED BY MEANS OF THE NEO-VIBROMETER AND MONOFILAMENT

\begin{tabular}{|c|c|c|c|c|}
\hline & \multicolumn{2}{|c|}{ Control group } & \multicolumn{2}{|c|}{ Neuropathic group } \\
\hline & Hallux & Heel & Hallux & Heel \\
\hline $\begin{array}{l}\text { Neo- } \\
\text { Vibrometer }\end{array}$ & $\begin{array}{l}\text { Mild } \\
\text { (23) }\end{array}$ & $\begin{array}{l}\text { Normal } \\
\text { (19) }\end{array}$ & $\begin{array}{l}\text { Mild } \\
\text { (15) }\end{array}$ & $\begin{array}{l}\text { Severe } \\
(10)\end{array}$ \\
\hline Monofilament & $\begin{array}{l}\text { Normal } \\
(8)\end{array}$ & $\begin{array}{l}\text { Normal } \\
\text { (7) }\end{array}$ & $\begin{array}{l}\text { Normal } \\
(10)\end{array}$ & $\begin{array}{l}\text { Severe } \\
(5)\end{array}$ \\
\hline
\end{tabular}

The between-days and within days ICCs for the Neovibrometer are presented in Table 2 . All the scores except one are well above 0.94 that indicating excellent reliability. Only the within-day reliability for the control subjects was slightly under 0.81 ( ICC $=0.77)$, which is still in the substantial reliability category [4].

TABLE 2. REPLICATION TO REPLICATION AND DAY-TO-DAY INTRACLASS CORRELATION COEFFICIENT FOR THE NEOVIBROMETER

\begin{tabular}{|c|c|c|}
\hline & Replication to Replication & Day-to-day \\
\hline All participants & 0.937 & 0.932 \\
\hline Control & 0.960 & 0.759 \\
\hline Neuropathic & 0.936 & 0.920 \\
\hline
\end{tabular}

The results of the panel of reliability measures, calculated for the first two measurements on the first day, can be seen in Table 4. Within-replication ICC is almost unchanged despite the fact that fewer repetitions but more subjects were used to calculate this value. All coefficients indicate that the within-replication reliability of the Neovibrometer is excellent.

TABLE 3. RESULTS OF THE CALCULATIONS OF THE PANEL OF RELIABILITY MEASURES (WITHIN DAY) FOR THE RIGHT HALLUX NEO-VIBROMETER VPT DATA FOR ALL THE PARTICIPANTS

\begin{tabular}{|c|c|}
\hline Reliability measure & Value \\
\hline PCC & 0.947 \\
\hline ICC & 0.943 \\
\hline
\end{tabular}

The reliability measures counted separately for Neovibrometer and Monofilament, based on the two measurements but for the control subjects only (Seen table 5). Both methods have excellent replication-to-replication reliability in the control group, with a location shift close 
to 0 and a scale shift close to 1 . The Pearson's correlation coefficient between the Neo-vibrometer and Monofilament was PCC $=0.86$.

TABLE 4. RELIABILITY MEASURES CALCULATED FOR THE NEO-VIBROMETER AND MONOFILAMENT SEPARATELY FOR THE RIGHT HALLUX

\begin{tabular}{lcc}
\hline $\begin{array}{l}\text { Reliability } \\
\text { measure }\end{array}$ & Neo-vibrometer & Monofilament \\
\hline ICC & 0.943 & 0.921 \\
\hline & VI. DISCUSSION &
\end{tabular}

In this study, the function of monofilament is very clear to detect presence of neuropathy. The Neovibrometer results showed that the range of loss of sensation beyond the off-scale category of monofilament. The results demonstrate that there is a range of detectable vibration amplitudes between severely neuropathic patients approximately two times greater than the monofilament. In this study, any patients who were categorized as normal when tested by using monofilament, but the category changes to mild neuropathy when tested using a neo-vibrometer. The previous study also show that the vibration test can detect the of loss sensation beyond monofilament test [5].

Furthermore, Examiner professionalism was important in measuring pressure sensation by Monofilament and affected the level of data reliability $[6,7,8]$. Robert et al. study demonstrated that a professionally trained examiner positively affected interrater reliability. Examiners of the current study were expert to evaluate pressure and vibration sensation by SWM and tuning fork and were trained by a professional neurologist [9].

Variation participant's affected the reliability [10]. Many studies reported low inter-rater reliability of SWM have examined healthy people $[8,11]$. The present study evaluated the diabetic patients with and without neuropathy and the ICC revealed a high inter-rater reliability. A number of monofilament, test location and examiner may affect the level of reliability. A prolonged period of the test may lead to fatigue and decrees participant's concentration. Decreased skin temperature is affected by plantar sensation [12].

The Intra-rater reliability demonstrated high ICC in replication-to-replication and day-to-day examination, similar to previous studies $[8,13,14]$. Only the reliability of right medial forefoot and left lateral forefoot were moderate. Collins et al. assessed the between-days intrarater reliability in healthy people and reported good reliability for the right foot and poor-to-moderate reliability for the left foot. Individual's variation and examiner proficient affected the reliability $[9,10]$. Studies demonstrated that vibration sensation test is appropriate for neuropathy diagnosis in diabetic patients [15]. Reliability of graduate tuning fork was assessed in diabetic and polyneuropathy patients [15].

The previous study related vibration test by using tuning fork demonstrated that within-day intra-and inter-rater reliability of tuning fork were excellent. However, between-days intra- and inter-rater reliability were moderate and poor, respectively [3].

\section{CONCLUSION}

The current study was demonstrated to investigate reliability of replication-to-replication and day-to-day inter- and intra-rater reliability in diabetic patients by monofilament and Neo-vibrometer. We conclude that the Neo-vibrometer can reliably measure VPT over a much wider range than the Monofilament. It is therefore a more appropriate tool for detecting the loss of sensation accurately.

\section{A. Ethical Considerations}

All procedures performed in studies were in accordance with the ethical standards of the STIK Muhammadiyah Pontianak.

\section{B. Funding}

This research received grant from The Ministry of Research, Technology, and Higher Education Republic of Indonesia.

\section{CONFLICT OF INTEREST}

The authors declare no conflict of interest.

\section{ACKNOWLEDGEMENTS}

The authors would like to thank The Ministry of Research, Technology, and Higher Education Republic of Indonesia has been funded this study, STIK Muhammadiyah Pontianak and also the community health center of Indonesia-Malaysia Border (Aruk and Entikong).

\section{REFERENCES}

[1] Pratama, K., Phutthikhamin, N. (2017). Implementation of Diabetic Foot Ulcer Prevention Program in the Provincial Hospital, Pontianak, West Borneo, Indonesia, The 5th AASIC 2017, p. $18-22$

[2] Deursen, R. W. M. van M. M. Sanchez, J. A. Derr, M. B. Becker, J. S. Ulbrecht and P. R. Cavanagh . Vibration perception threshold testing in patients with diabetic neuropathy: ceiling effects and reliability . 2001: Diabetes UK. Diabetic Medicine,, $469 \pm 475$

[3] Bagherzadeh Cham M, Mohseni-Bandpei MA, Bahramizadeh M, Kalbasi S, Biglarian A. Reliability of Semmes- Weinstein Monofilaments and Tuning Fork on Pressure and Vibration Sensation Measurements in Diabetic Patients. Iranian Rehabilitation Journal. 2019; 17(1):1-8 http://dx.doi.org/10.32598/irj.17.1.1

[4] Landis RJ, Koch GG. The measurement of observer agreement for categorical data. Biometrics 1977; 33X 159 \pm 174 .

[5] Shaffer S, Harrison A, Brown K, Brennan K. Reliabil- ity and validity of semmes-weinstein monofilament testing in older community-dwelling adults. Journal of Geriatric Physical Therapy. 2005; 28(3):112-3. [DOI:10.1519/00139143200512000-00019]

[6] Anderson A, Croft R. Reliability of semmes weinstein monofilament and ballpoint sensory testing, and volun- tary muscle testing in Bangladesh. Leprosy Review. 1999; 70(3):30513. [DOI:10.5935/0305-7518.19990034] [PMID]

[7] Collins S, Visscher P, De Vet HC, Zuurmond WW, Perez RS. Reliability of the semmes weinstein monofilaments to measure coetaneous sensibility in the feet of healthy sub- jects. Disability and Rehabilitation. 2010; 32(24):2019-27. [DOI:10.3109/09638281003797406] [PMID]

[8] Roberts A, Nicholls P, Maddali P, Van Brakel W. Ensuring intertester reliability of voluntary muscle and monofilament sensory testing in the INFIR Cohort study. Leprosy Review. 2007; 78(2):122-30. [PMID] 
[9] De Vet HC, Terwee CB, Knol DL, Bouter LM. When to use agreement versus reliability measures. Journal of Clini- cal Epidemiology. 2006; 59(10):1033-9. [DOI:10.1016/j.jclinepi.2005.10.015] [PMID]

[10] Rozental TD, Beredjiklian PK, Guyette TM, Weiland AJ. Intraand interobserver reliability of sensibility testing in asymptomatic individuals. Annals of Plastic Surgery. 2000; 44(6):605-9. [DOI:10.1097/00000637-200044060-00005] [PMID]

[11] Doeland HJ, Nauta JJ, van Zandbergen JB, van der Eerden HA, van Diemen NG, Bertelsmann FW, et al. The relation- ship of cold and warmth cutaneous sensation to age and gender. Muscle \& Nerve. 1989; 12(9):712-5. [DOI:10.1002/ mus.880120903] [PMID]

[12] Mawdsley RH, Behm-Pugh AT, Campbell JD, Carroll CR, Chernikovich KA, Mowbray MK, et al. Reliability of measurements with semmes-weinstein monofilaments in individuals with diabetes. Physical and Occupational Therapy in Geriat- rics. 2004; 22(3):19-36. [DOI:10.1080/J148v22n03_02]

[13] Van Brakel WH, Khawas IB, Gurung KS, Kets CM, van Leerdam ME, Drever W. Intra- and inter-tester reliability of sensibility testing in leprosy. International Journal of Leprosy and Other Mycobacterial Diseases. 1996; 64(3):287-98.

[14] Cornblath D. Diabetic neuropathy: Diagnostic methods. Advanced Studies in Medicine. 2004; 4(8A):650-61.

[15] Merkies IS, Schmitz PI, van der Meche FG, van Doorn PA. Reliability and responsiveness of a graduated tuning fork in immune mediated polyneuropathies. The Inflammatory Neuropathy Cause and Treatment (INCAT) Group. Journal of Neurology, Neurosurgery, and Psychiatry. 2000; 68(5):669- 71. [DOI:10.1136/jnnp.68.5.669] [PMID] [PMCID] 